\title{
ХРОНИКА
}

DOI: https://doi.org/10.17308/geology.2020.3/3013

ISSN 1609-0691

Поступила в редакцию: 02.09.2020

Принята к публикации: 02.09 .2020

Опубликована онлайн: 30.09 .2020

Received: 02.09.2020

Accepted: 02.09.2019

Published online: 30.09 .2020

\section{К 70-летию Александра Николаевича Плаксенко}

\author{
C2020 В. М. Ненахов ${ }^{\bowtie}$
}

Воронежский государственный университет, Университетская пл., 1, 394018, Воронеж, Российская Федерация

\section{To the 70th anniversary of Alexander N. Plaksenko}

\author{
C 2020 V. M. Nenahov ${ }^{凶}$ \\ Voronezh State University, 1 Universitetskaya pl., 394018, Voronezh, Russian Federation
}

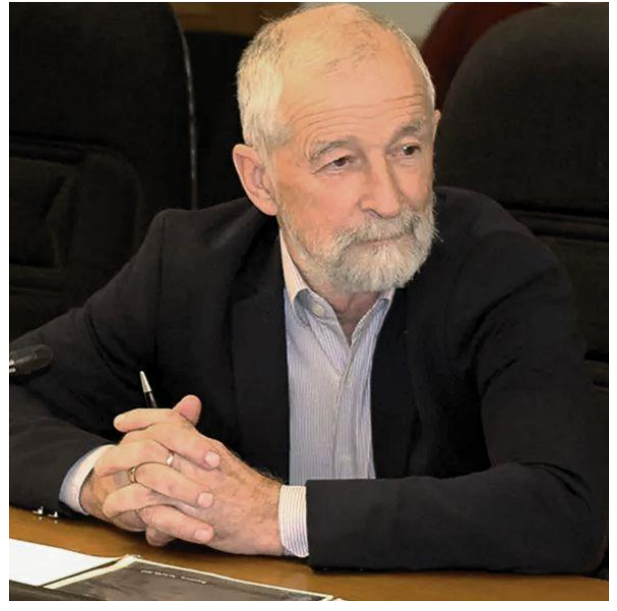

25 октября 2020 года исполняется 70 лет со дня рождения доктору геолого-минералогических наук, Академику Российской академии горных наук, заслуженному геологу России, Председателю Воронежского регионального отделения Российского Геологического общества - Александру Николаевичу Плаксенко.

А. Н. Плаксенко окончил геологический факультет Воронежского государственного университета в 1974 г., и с тех пор его научно-педагогическая и общественная деятельность неразрывно связана с родным университетом.
С 1974 по 1978 гг. А. Н. Плаксенко работает в Проблемной научно-исследовательской лаборатории геологии и минерального сырья ЦЧЭР ВГУ в должности младшего, а затем старшего научного сотрудника. С 1978 по 1981 гг. работает в должности старшего преподавателя кафедры минералогии и петрографии геологического факультета, продолжая интенсивно заниматься научной работой. В эти годы научные интересы А. Н. Плаксенко связаны с детальным исследованием типоморфизма комплекса акцессорных минералов никеленосных интрузий Воронежского кристаллического массива (ВКМ). Результаты этих исследований были обобщены в монографии «Акцессорные минералы дифференцированных никеленосных интрузий Воронежского кристаллического массива», ставшей по сути дела первой монографической работой по типоморфизму акцессориев докембрийских мафит-ультромафитовых формаций. Это монография и легла в основу кандидатской диссертации, защищенной А.Н. Плаксенко в 1981 году в Московском геологоразведочном институте.

С 1981 по 1992 гг. А. Н. Плаксенко работает ведущим научным сотрудником ПНИЛ геологии и минерального сырья ЦЧЭР ВГУ, являясь научным руководителем ряда научных проектов и грантов. В эти годы основные научные интересы А. Н. Плаксенко связаны с проблемами петрологии и рудоносности производных ультрамафит-мафитового магматизма докембрия.

Контент доступен под лицензией Creative Commons Attribution 4.0 License.

The content is available under Creative Commons Attribution 4.0 License.

\footnotetext{
${ }^{凶}$ Ненахов Виктор Миронович, e-mail: viktor.nenahov@mail.ru
} 
На основании детальных исследований минеральных парагенезисов была впервые доказана мантийная природа норит-диоритовых интрузий ВКМ и связанных с ними никелевых сульфидных руд, показана важная роль в их образовании процессов ассимиляции и контаминации магматическим расплавам корового салического вещества. А. Н. Плаксенко с соавторами впервые всесторонне был изучен комплекс основных и ультраосновных ксенолитов в докембрийских норитах ВКМ. Серия публикаций, посвящённых этому вопросу получила широкий резонанс, как в нашей стране, так и за рубежом. В этот же период А. Н. Плаксенко впервые в мировой практике осуществлено детальное исследование типоморфизма акцессорных минералов и их парагенезисов коматиитовых серий, что позволило с новых позиций подойти к решению проблемы генезиса этих уникальных магматических образований.

Одним из первых А. Н. Плаксенко обращает внимание на исключительную информативность минералов группы хромшпинелидов в решении дискуссионных проблем петрологии и рудоносности ультрамафит-мафитовых магматических серий докембрия и фанерозоя. Результатом многолетних комплексных исследований минералов этой группы явилось издание фундаментальной монографии «Типоморфизм акцессорных хромшпинелидов ультрамафит-мафитовых магматических формаций», получившей широкую известность в научных геологических кругах. Это позволило А. Н. Плаксенко в 1992 году защитить одноименную докторскую диссертацию по совокупности работ в Санкт-Петербургском государственном университете.

С 1993 по 1998 гг. А. Н. Плаксенко является заведующим ПНИЛ геологии и минерального сырья ЦЧЭР и заместителем декана геологического факультета по научной работе. С 1995 по 2003 гг. А. Н. Плаксенко работает в должности профессора кафедры исторической геологии и палеонтологии геологического факультета.

В этот период А. Н. Плаксенко является Соровским стипендиатом (1995 г.), стипендиатом Президента России для выдающихся ученых (1995-1997 гг.), а в 1999 году избирается действительным членом Российской академии горных наук.

С 2003 года, не оставляя научно-педагогической деятельности, А. Н. Плаксенко переходит на государ-

Конфликт интересов: Авторы декларируют отсутствие явных и потенциальных конфликтов интересов, связанных с публикацией настоящей статьи.

Для циитирования: Ненахов В. М. К 70-летию Александра Николаевича Плаксенко // Вестник Воронежского государственного университета. Серия: Геология. 2020. №3. С. 9697. DOI: https://doi.org/10.17308/geology.2020.3/3013

Виктор Миронович Ненахов - д. Г.-м. Н., профессор, декан геологического факультета, Воронежский государственный университет, Воронеж, Российская Федерация;

E-mail: viktor.nenahov@mail.ru

Автор прочитал и одобрил окончательный вариант рукописи. ственную службу, возглавив отдел геологии и лицензирования по Воронежской области («Воронежнедра») Департамента по недропользованию ЦФО с присвоением классного чина советника государственной гражданской службы РФ. В этот период внимание А. Н. Плаксенко приковано к проблеме освоения и расширения минерально-сырьевых ресурсов ЦЧР, и прежде всего - к проблеме рационального использования отходов обогащения горнодобывающих и горноперерабатывающих предприятий Воронежской области, являющихся важнейшим техногенным источником рудного сырья в условиях современной экономической реальности. В 2010 году А. Н. Плаксенко присваивается почетное звание «Заслуженный геолог России».

С 2012 года и по сей день А. Н. Плаксенко является куратором Воронежского проекта АО «УГМК» по изучению и освоению месторождений сульфидных медноникелевых руд в Новохоперском районе Воронежской области - крупнейшей никеленосной провинции России вслед за Норильским регионом и Кольским полуостровом.

А. Н. Плаксенко видный ученый известный далеко за пределами России автор - 3 монографий, более 170 научных публикаций, 12 патентов на изобретение, участник крупнейших научных форумов. Свою работу А. Н. Плаксенко успешно сочетает с общественной деятельностью, являясь председателем Воронежского регионального отделения Российского геологического общества.

Общительность, скромность, доброжелательность и добропорядочность, справедливость и принципиальность в суждениях и поступках снискали А. Н. Плаксенко широкую известность и заслуженное уважение в студенческой среде, коллективах научных сотрудников и преподавателей Воронежского университета, а также широкого круга научных и производственных организаций геологической отрасли страны.

Коллектив геологического факультета Воронежского государственного университета, от всей души поздравляет Александра Николаевича, находящегося в рассвете физических и творческих сил, с юбилеем и желает ему крепкого здоровья и новых творческих успехов.

Conflict of interests: The authors declare the absence of obvious and potential conflicts of interest related to the publication of this article.

For citation: Nenahov V. M. To the 70th anniversary of Alexander N. Plaksenko. Vestnik Voronezhskogo gosudarstvennogo universiteta. Seriya: Geologiya = Proceedings of Voronezh State University. Series: Geology, 2020, No. 3, pp. 96-97. DOI: https://doi.org/10.17308/geology.2020.3/3013

Victor M. Nenahov - PhD, Dr. habil. in Geol.-Min., professor, Dean of the Faculty of Geology, Voronezh State University, Voronezh, Russian Federation;

E-mail: viktor.nenahov@mail.ru

Author have read and approved the final manuscript 